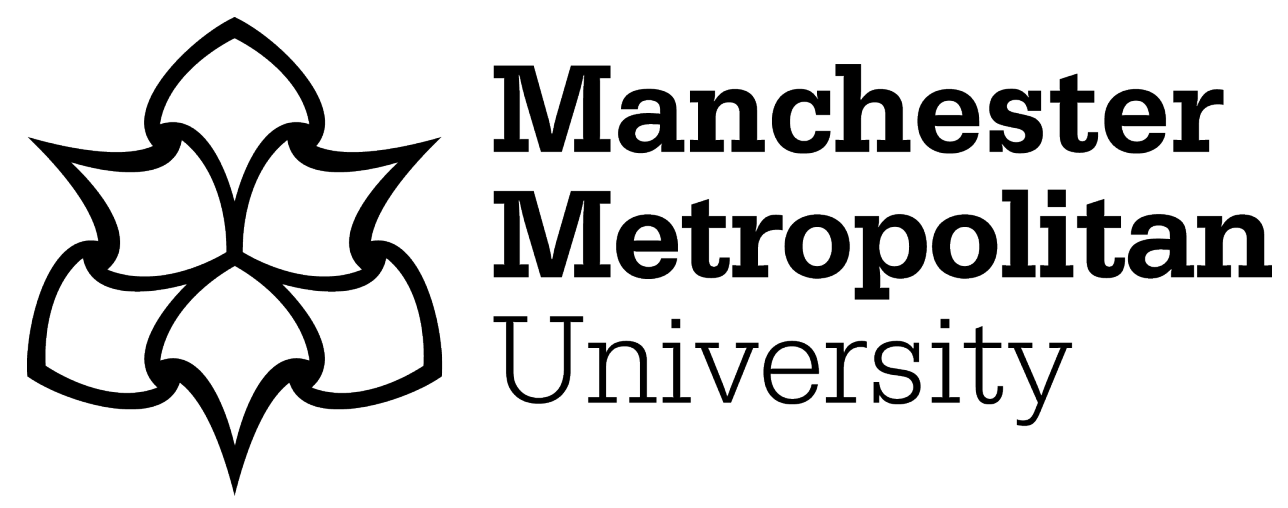

Niedderer, Kristina and Townsend, Katherine (2017) Editorial: Exploring aesthetics and cultural meanings through craft. Craft Research, 8 (1). pp. 3-8. ISSN 2040-4689

Downloaded from: https://e-space.mmu.ac.uk/622129/

Publisher: Intellect

DOI: https://doi.org/10.1386/crre.8.1.3_2

Please cite the published version 
CRRE 8.1 Editorial

\title{
Exploring Aesthetics and Cultural Meanings through Craft
}

\author{
Kristina Niedderer and Katherine Townsend
}

Aesthetics in its original Kantian sense is still often traded as the exclusive domain for the Fine Arts, including areas such as: music, painting, literature, architecture, sculpture, dance, theatre, poetry, photography and film in their discussions (Levinson 2003: xi), but not design or craft. This selectivity appears to arise from an understanding of aesthetics as being "the branch of philosophy devoted to conceptual and theoretical inquiry into art and aesthetics." (Ibid. p.3) where art, and therefore the consideration of aesthetics, relates to the perception of form for its own sake (Ibid. p.3ff).

In contrast, craft and by extension design, do not seem to be as commonly associated and discussed with regard to aesthetics, possibly because of their connection to focused making and functionality. Current dominant literature on craft (e.g. Adamson (2007, 2013) Alfoldy (2007), Crawford (2009), Frayling (2011), Sennett (2008)) seems to accept this idea that craft is not connected with, or quite 'worthy' of aesthetic consideration, offering no directed discussion of, or reference to the role of aesthetics in craft $^{1}$. Where aesthetics is discussed in earlier writings by theorists, philosophers and anthropologists (e.g. Dormer, 1997; Adorno, Bell, Benjamin, Collingwood, Morris, Wallace in Adamson, 2010: 147, 388, 391, 396, 401-3, 417-23, 466, 561), it is either discussed in general, often Kantian terms (Shusterman, 2003: 781 ) in relation to craft. Or, references tend to deal with 'technical aesthetics' particularly linked to issues raised during the Arts and Crafts movement and the Bauhaus era.

Two authors taking a more specific approach are Risatti (2010) with his inquiry into function and aesthetic expression, who seeks to understand and negotiate craft in the traditional Kantian canon of aesthetics; and Chattophadyay (in Adamson, 2010: 194) who discusses 'everyday aesthetics' in the context of Indian craft developments. Both views are of interest here for different reasons: on the one hand, Risatti relates aesthetics to expression; on the other hand, Chattophadyay considers aesthetics outside of the typical Western canon. Both concepts open up new views, which are increasingly important to, and indicative of contemporary craft thinking, because they indicate a broadening of the understanding of aesthetics. This developing understanding is based on the understanding that "perceptible properties of things are aesthetic" (Levinson 2003: 6). This means, aesthetics does not just have to relate to visual stimuli, but can relate to all sensory stimuli - visual, oral, aural, smell and touch. Shusterman's concept of soma-aesthetics (2011) has been important in this context in the broadening of aesthetic theory and its practical applicability. Somaaesthetics proposes the body as a site of aesthetic experience, and thus includes all the senses. Furthermore, it suggests that through the body and the imitation of its movements (e.g. body posture, gesture, movement, or facial expression) empathic experience is created (Shusterman, 2011, p.155). Relating aesthetics with the body and its sensory experiences, also closely links it to related interpretations, such as

\footnotetext{
${ }^{1}$ E.g. the notion of aesthetics neither appears in the contents list or the index of these works
} 
emotional responses, cultural values and moral judgments, where it constitutes the balance between various contrasting stimuli, perceived as more or less harmonious.

This issue of Craft Research explores the relationship of this broader understanding of aesthetics with culture and craft in a number of different ways.

In his article on the 'Trons', Snakebeing is concerned with craft aesthetics, which he understands as both the qualities and experiences of the made through the sometimes inaccurate and unpredictable process of hand-making with reused and 'flimsy' materials. He conjures both the satisfaction of making by hand as considered by Crawford (2009), and the Eastern notion and aesthetics of 'wabisabi' that takes pride in the irregularities of the imperfect. The aspect of making is also important in Choi's article on glass and ceramic wares, through an approach subordinated by the exploration of cultural aesthetics and the uncanny. Borne out of his experience of another 'alien' culture when coming to study in Britain, and the encounters of linguistic misunderstandings and cultural 'gaps', his work and article traces the source of this discomfort, which he seeks to turn to good use by creating enhanced multicultural understandings. He does so through generating objects imbued with multiple cultural characteristics that facilitate uncanny experiences because they cannot easily be placed, and by extension allows people to explore their own perceptions, preconceptions and cultural understandings.

Taking the aspect of cultural aesthetics a step further, Rajangam reports on a study of Hampi craft and values which underpin the ideas and questions relating to preservation and preservation projects. The challenges of participatory research, which necessarily has to be a tool in such projects, also raises questions of the benefit and value for the participant population of craftsmen and women. Preserving indigenous craft practices requires understanding and negotiating cultural diversity, values and contrasts, not least judgments of what is worth preserving and why, and whose aesthetic and other judgments should be considered.

In a similar vein, Divakala and Muthian's paper 'Temple Cloth to Textile Craft' discusses ongoing developments of the craft of Kalamkari, a traditional style of handpainting and block-printing practiced in the town of Srikalahasti in Andhra Pradesh. In India, the name Kalamkari, is derived from 'kalam', an ancient pen-like tool, and 'kari', meaning craftsmanship. Following its revival in 1957 the practice found support based on the production of a range of new textile applications and was transformed from a specialist artisanal craft applied within religious environs into one of broader decorative, and utilitarian appeal. Through case studies of nationally recognized Kalamkari artists, the authors demonstrate the tensions that arise when trying to balance desired aesthetics with issues of cultural heritage and cultural identity. The article reinforces the challenge acknowledged by Grace Cochrane in her contribution to NeoCraft: Modernity and the Crafts (Alfoldy 2007), that: "as well as providing pleasure and satisfaction to the maker and designer, a practice also has to be a sustainable, viable reality and successfully find its marketplace."(Cochrane quoted in Anicef, 2010: 7).

Kane's paper continues the theme of craft as an outcome generated by particular connections between people and place. Building on Cresswell's idea that 'place' is not just a thing in the world but a way of understanding the world (2014: 34), the 
author reflects on a practice-led research project into the use of flax-fibres cultivated in the Midlands, UK. The article reports on the proliferation of the materials industry and the recent resurgence in the use of flax fibres within new, potentially recyclable, textile composites. Using her own experimental creative experimentation with a range of technologies to decoratively finish the flax based substrates, Kane then starts to build an argument for the role that craft might play in developing an approach to materials that focuses on the 'place' where they are grown and produced, as a sustainable craft approach to design.

The review of Make:Shift 2016 by Hardy and Arm, reflects on the biannual Crafts Council innovation event, held at the Museum of Science and Industry, Manchester. The programme featured cutting-edge work by 55 makers, academics and creatives working on the boundary between craft, art, science and engineering. Informed by the underpinning themes of 'social innovation, sustainability and wellbeing' advances in craft were revealed through insights into 'how makers collaborate and catalyse innovation in other sectors and industries... [including] robotics, smart materials, bio design, connected wearables alongside more traditional craft disciplines.' (Crafts Council 2016) The focus on crafting connections was reinforced in keynotes by Mark Mark Miodownik, The Insitute of Making, UCL, Caroline Till, FranklinTill Studio, Maker and Conversation spaces, encouraging active discourse into the potential ways in which craft can impact upon socio-cultural engagement.

Dillon's review of the book Crafting Textiles in the Digital Age, (Nimkulrat, Kane and Walton, 2016) further elaborates the ambiguity between the handmade, machine made an digital production. It emphasises the need for our emotional relationship with objects and the respect for the handmade and the resurgence of the value of craft as an expression of this.

Handcock's detailed overview of the End of Fashion exhibition, staged alongside the conference of the same name, also highlights the thread of interconnected making and thinking, as expressed through a variety of mediums and processes. Curated by Sue Prescott and Dr Adam Geczy, the exhibition brought together fourteen artists and designers across two spaces in the College of Creative Arts at Massey University in Wellington, New Zealand. In contrast to the literal interpretations of the theme as predicting the 'death of fashion', the exhibition was conceived as an end point in and of itself, an autonomous, alternate zone where designers could show ideas as fragmentary or hypothetical forms, displaced from the body and scenes of life (Geczy and Prescott 2016. p. 1-2). The overriding theme was a critique of the contemporary fashion industry, both dark and playful; through evocations of absent or alternative visions of the human body; investigations into the aesthetic, material and ethical concerns of fashion, and visually communicating relationships between technical craftsmanship and design within cultural contexts. The underlying question raised by the exhibition, of 'if this is the end, what is the future?' remained largely unanswered, but as Handcock acknowledges, 'the death of the author' (Barthes 1977) was palpable through works by Lacko, Abbadi, Salin and Rissanen who predicted a shift in fashion's powerbase from designer to consumer.

Timo Rissanen is also the subject of the Portrait Section in this issue. His autobiographical essay describing his recent transition from fashion design to hand 
embroidery, in particular poetry cross-stitched by hand. The practice integrates Rissanen's interests in sustainability and recent political developments in the United States. Here, craft becomes a potent site for political activism in the form of crossstitched prose; the economy of words, made in real time, challenging the speed and content of the digital age of communication it replicates. Building on Parker's (2010) concluding chapter in the Subversive Stitch, that frames embroidery an art ripe for revolutionary thought and protest, he combines the aesthetics of the historical sampler with text-style messages imbued with contemporary cultural meaning.

\section{A word of thanks}

We are delighted to present Volume 8.1 of Craft Research. As always, many people have been involved in the realisation of this issue. We wish to thank all our contributors, as well as those authors whose submissions we regrettably had to turn away. Our gratitude also extends to all our advisors as well as to our reviewers for their excellent work. Their constructive advice and feedback to authors is an essential part in fulfilling the developmental role of the journal and in advancing the field. We further wish to thank Intellect Publishers for their continued support for the journal, in particular our journal's manager, Bethan Ball, and her team.

Kristina Niedderer and Katherine Townsend February 2017

\section{References}

Anicef, J. (2010). Tracing Emerging Modes of Practice: Craft Sector Review, Ontario Arts Council, Available

at: http://www.arts.on.ca/oac/media/oac/Publications/Research\%20Reports\%20EN-

FR/Program\%20Evaluation/Craft-Report_EN_Final_AODA.pdf. Accessed 8 February 2017.

Adamson D. (2007). Thinking through Craft. Oxford: Berg.

Adamson, D. (2013). The Invention of Craft. Oxford: Berg.

Adamson, D. (2010). Th Craft Reader. Oxford: Berg.

Alfoldy, S. (ed.) (2007). NeoCraft: Modernity and the Crafts. The Press of the Nova Scotia College of Art and Design.

Barthes, R. (1977). 'The Death of the Author', in R. Barthes, Image / Music / Text (trans. Stephen Heath), New York: Hill and Wang, pp. 142-147.

Crawford, M. (2009). The Case for Working with your Hands. London: Penguin Books (Viking).

Crafts Council (2016) Make:Shift 2016, Available at:http://www.craftscouncil.org.uk/whatwe-do/makeshift/ Accessed 8 February 2017.

Cresswell, T (2014). Place: An Introduction, $2^{\text {nd }}$ Edition, Wiley-Blackwell.

Dormer, P. (ed.) (1997). The Culture of Craft: Status and future. Manchester: Manchester University Press.

Frayling, C. (2011). On Craftsmanship: towards a new Bauhaus. London: Oberon Books.

Geczy, A. and Prescott, S. (2016), The End of Fashion, exhibition catalogue, 8-9 December 2016, Wellington New Zealand: College of Creative Arts, Massey University. 
Levinson, J. (ed.) (2003). The Oxford Handbook of Aesthetics. Oxford: Oxford University Press.

Nimkulrat, N., Kane, F. and Walton, K. (2016). Crafting Textiles in the Digital Age, London and New York: Bloomsbury.

Parker, R. (2010), The Subversive Stitch. Embroidery and the Making of the Feminine. London \& New York: I.B. Tauris.

Risatti, H. (2010). A Theory of Craft: Function and aesthetic expression. Chapel Hill: University of California Press.

Sennett, R. (2008). The Craftsman. London: Penguin Books (Allan Lane).

Shusterman, R. (2003). Aesthetics and Postmodernism. In J. Levinson The Oxford Handbook of Aesthetics. Oxford: Oxford University Press, pp. 771-782.

Shusterman, R. (2011). Somatic style. The Journal of Aesthetics and Art Criticism, 96(2), 147-159. 